\title{
Short Communication: Conception Rates Following Detection of Estrus and Timed Al in Dairy Cows Synchronized Using GnRH and PGF $2 \alpha$
}

\author{
J. C. Dalton, ${ }^{1}$ R. Manzo, ${ }^{1}$ A. Ahmadzadeh, ${ }^{1}$ B. Shafii, ${ }^{2}$ W. J. Price,${ }^{2}$ and J. M. DeJarnette ${ }^{3}$ \\ ${ }^{1}$ Animal and Veterinary Science Department, and \\ ${ }^{2}$ Statistical Programs, College of Agricultural and Life Sciences, University of Idaho, Moscow 83844 \\ ${ }^{3}$ Select Sires, Inc., Plain City, OH 43064
}

\section{ABSTRACT}

The objective of this study was to compare conception rates of cows exhibiting spontaneous estrus and receiving artificial insemination (AI) before completion of a timed AI protocol with cows that did not display estrus spontaneously, but were inseminated after 1 of 3 GnRH-PGF ${ }_{2 \alpha}$ protocols. Cows $(\mathrm{n}=432)$ in 2 herds were administered GnRH on d -7 and were tail-chalked daily. Cows detected in estrus before $\mathrm{d} 0$ were inseminated immediately. Cows not detected in estrus by d 0 were administered $\mathrm{PGF}_{2 \alpha}$ and were tail-chalked daily until $48 \mathrm{~h}$ after $\mathrm{PGF}_{2 \alpha}$. Cows detected in estrus from $\mathrm{d}-7$ to $48 \mathrm{~h}$ after $\mathrm{PGF}_{2 \alpha}$ were inseminated and designated as treatment $A(n=46)$. Cows not detected in estrus and not inseminated by $48 \mathrm{~h}$ after $\mathrm{PGF}_{2 \alpha}$ were assigned randomly to receive either GnRH $48 \mathrm{~h}$ after $\mathrm{PGF}_{2 \alpha}$ and timed AI $16 \mathrm{~h}$ later (treatment $\mathrm{B} ; \mathrm{n}=132$ ), or $\mathrm{GnRH}$ and timed $\mathrm{AI} 64 \mathrm{~h}$ after $\mathrm{PGF}_{2 \alpha}$ (treatment $\mathrm{C} ; \mathrm{n}=127$ ), or timed AI $64 \mathrm{~h}$ after $\mathrm{PGF}_{2 \alpha}$ (treatment $\mathrm{D} ; \mathrm{n}=127$ ). Pregnancy was diagnosed 38 to $45 \mathrm{~d}$ after AI by palpation per rectum of uterine contents. Nearly $11 \%$ of all cattle exhibited spontaneous estrus and received immediate AI. Herd did not influence the percentage of cows detected in estrus and inseminated. Conception rates did not differ among treatments. Conception rates differed between herds, but no interaction of herd $\times$ treatment was detected. No differences were detected between herds for days in milk, milk production, AI service number, or parity.

(Key words: conception rate, detection of estrus, synchronization, timed $\mathrm{AI}$ )

Ovsynch (GnRH-7 d-PGF ${ }_{2 \alpha}-2$ d-GnRH-0 to $24 \mathrm{~h}-$ timed AI; Pursley et al., 1995, 1997) was designed to synchronize ovulation; thereby allowing timed AI of all cows without detection of estrus. The ability of Ovsynch to synchronize ovulation, however, is dependent upon

Received April 11, 2005.

Accepted August 18, 2005.

Corresponding author: Joseph C. Dalton; e-mail: jdalton@uidaho. the stage of follicular development at the time of the initial GnRH injection (Vasconcelos et al., 1999). Consequently, presynchronization of estrous cycles (Presynch) by using 2 injections of $\mathrm{PGF}_{2 \alpha} 14 \mathrm{~d}$ apart, with the second injection either 12 (Moreira et al., 2001; ElZarkouny et al., 2004) or $14 \mathrm{~d}$ (Navanukraw et al., 2004) before the initiation of Ovsynch has been shown to increase conception rates by optimizing the stage of the estrous cycle (between d 5 and 13) at initiation of Ovsynch. Nevertheless, presynchronization is a time- and labor-intensive protocol that is most effective in scheduling first services. Presynchronization was not designed nor is it practical for application to previously inseminated cows that failed to conceive. Ovsynch, without presynchronization, remains an effective breeding tool, especially for second and greater AI services.

Fricke et al. (1998) observed an 84\% incidence of ovulation after the second injection of $\mathrm{GnRH}$ when Ovsynch was initiated at various stages of the estrous cycle. Vasconcelos et al. (1999) reported that ovulation to the second GnRH ranged from 81 to $94 \%$ with an overall average synchronization rate of $87 \%$. Vasconcelos et al. (1999) stated that initiation of Ovsynch in cows in the second half of the estrous cycle resulted in a lower synchronization rate, with failures primarily due to ovulation before the second GnRH injection. Furthermore, DeJarnette et al. (2001) reported a 20\% incidence of spontaneous estrus (before the second injection of $\mathrm{GnRH}$ ) in lactating dairy cows enrolled in Ovsynch. Consequently, conception rates of cows enrolled in Ovsynch, and displaying spontaneous estrus and (or) spontaneous ovulation before completion of the protocol, would likely be compromised when inseminated at a fixed time.

Pursley et al. (1998) investigated the optimal time for AI after the second GnRH injection of the Ovsynch protocol and reported that lactating dairy cows inseminated at $0,8,16$, and $24 \mathrm{~h}$ after $\mathrm{GnRH}$ had similar conception rates, whereas those inseminated $32 \mathrm{~h}$ after GnRH had reduced conception rates. Nevertheless, conception rates at 0 to $32 \mathrm{~h}$ produced a quadratic response curve, with the greatest numerical value found for cows 


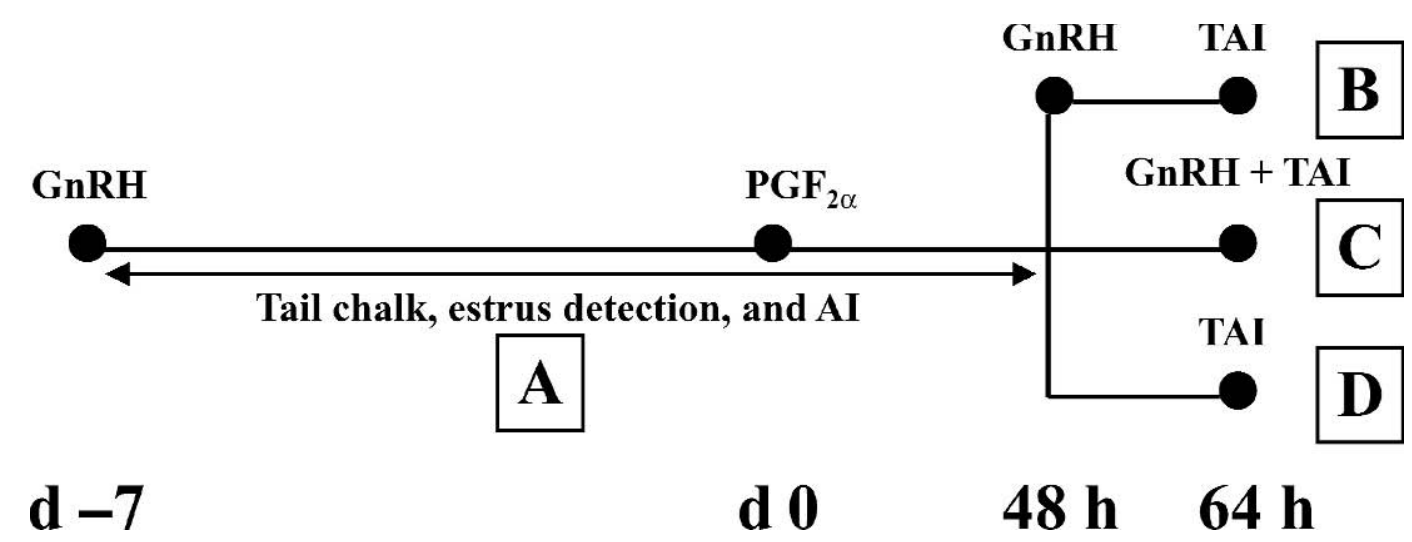

Figure 1. All cows were treated with $\mathrm{GnRH}$ on $\mathrm{d}-7$. Routine daily tail chalk application and detection of estrus was conducted from d -7 to 0 . Cows detected in estrus before $\mathrm{d} 0$ were inseminated, designated as treatment $\mathrm{A}$, and removed from the remainder of the protocol. Cows not detected in estrus by d 0 received $\mathrm{PGF}_{2 \alpha}$ and continued to receive daily tail chalk for $48 \mathrm{~h}$. All cows detected in estrus up to 48 $\mathrm{h}$ after $\mathrm{PGF}_{2 \alpha}$ received $\mathrm{AI}$ and also were designated as treatment $\mathrm{A}$. Cows not detected in estrus and not inseminated by $48 \mathrm{~h}$ were assigned randomly to 1 of 3 treatments: GnRH $48 \mathrm{~h}$ after $\mathrm{PGF}_{2 \alpha}$ and timed $\mathrm{AI} 16 \mathrm{~h}$ later (treatment $\mathrm{B}$ ); GnRH and timed AI $64 \mathrm{~h}$ after PGF $2 \alpha$ (treatment $\mathrm{C}$ ); or timed $\mathrm{AI} 64 \mathrm{~h}$ after $\mathrm{PGF}_{2 \alpha}$ (treatment D).

inseminated at $16 \mathrm{~h}$ after GnRH (Pursley et al., 1998). Given that: 1) Ovsynch (even without presynchronization) remains an effective breeding tool, and 2) spontaneous estrus may occur in up to $20 \%$ of cattle enrolled in Ovsynch without the benefit of presynchronization (DeJarnette et al., 2001), the objective of this study was to compare conception rates of cows exhibiting spontaneous estrus and receiving AI before completion of a timed AI protocol with those that did not display estrus spontaneously, but were inseminated after 1 of 3 GnRH-PGF ${ }_{2 \alpha}$-based timed AI protocols.

Two commercial herds located in Idaho and Utah participated in the study. Cattle were housed in combination dry-lot, free-stall housing on both dairies. Average yearly milk yield (and herd size) was 10,454 kg per cow (500 cows) and 11,500 kg per cow (975 cows) for the Idaho and Utah herds, respectively. Cattle were fed a TMR formulated to meet or exceed requirements for lactating dairy cows (NRC, 2001). Cattle were restrained in headlocks once daily to facilitate chalking tails, detection of estrus based on rubbed tail chalk (roughened tailhead hair), and AI. Semen used for AI was from multiple suppliers.

Cows $(\mathrm{n}=432)$ in 2 herds diagnosed as not pregnant to a previous $\mathrm{AI}$ and cows $>60 \mathrm{~d}$ postpartum (and not yet inseminated) were treated with GnRH (100 $\mu \mathrm{g}$; Cystorelin, Merial, Athens, GA) on d - 7 (Figure 1). Routine tail chalking and detection of estrus was conducted from $\mathrm{d}-7$ to 0 . Cows detected in estrus according to chalk removal (roughened tailhead hair) before $\mathrm{d} 0$ were inseminated immediately. Cows not detected in estrus by $\mathrm{d} 0$ were administered $\mathrm{PGF}_{2 \alpha}$ (25 mg; Lutalyse, Pfizer, New York, NY) and continued to receive daily tail chalk until $48 \mathrm{~h}$ after $\mathrm{PGF}_{2 \alpha}$. All cows detected in estrus from $\mathrm{d}-7$ to $48 \mathrm{~h}$ after $\mathrm{PGF}_{2 \alpha}$ were inseminated immediately and were designated as treatment $\mathrm{A}$ ( $\mathrm{n}=$ 46). Cows that were not detected in estrus and not inseminated by $48 \mathrm{~h}$ after $\mathrm{PGF}_{2 \alpha}$ were assigned randomly to 1 of 3 treatments: 1$) \mathrm{GnRH}(100 \mu \mathrm{g}) 48 \mathrm{~h}$ after $\mathrm{PGF}_{2 \alpha}$ and timed AI $16 \mathrm{~h}$ later (treatment $\mathrm{B} ; \mathrm{n}=132$ ); 2) $\mathrm{GnRH}(100 \mu \mathrm{g})$ and timed AI $64 \mathrm{~h}$ after $\mathrm{PGF}_{2 \alpha}$ (treatment $\mathrm{C} ; \mathrm{n}=127)$, or 3 ) timed $\mathrm{AI} 64 \mathrm{~h}$ after $\mathrm{PGF}_{2 \alpha}$ without GnRH (treatment D; $\mathrm{n}=127$ ) (Figure 1). Pregnancy was diagnosed 38 to $45 \mathrm{~d}$ after AI by palpation per rectum of uterine contents.

Conception rates were analyzed using a logistic regression model including the effects of herd, treatment, and 2-way treatment interactions, in addition to DIM, milk production, AI service number, and parity. The required sample size to achieve a $10 \%$ depression in conception rate is 415 dairy cows, which corresponded to a $5 \%$ level of significance, with a power of $70 \%$ (Hsieh et al., 1998). Days in milk, milk production, AI service number, and parity were compared between herds using the GLM procedure in SAS (SAS Institute, 2000). All computations were carried out using SAS (2000).

Nearly $11 \%$ of all cows (46/432) enrolled exhibited spontaneous estrus, were inseminated, and removed from the remainder of the protocol (treatment A). The percentage of cows detected in estrus and inseminated (treatment A) did not differ between herds. Conception rates did not differ among treatments (Table 1). Further, with 432 observations and an overall conception rate of $24.7 \%$, at least $70 \%$ power is achieved for the detection of odds ratios less than 0.5 or greater than 2.0 with a significance level equal to $5 \%$. These odds ratios translate to a change in the probability of conception to less than $15 \%$ or greater than $40 \%$ (Hsieh et al., 
Table 1. Effect of AI protocol on conception rates (\%, with no. pregnant/no. inseminated in parentheses) of lactating dairy cows.

\begin{tabular}{|c|c|c|c|c|c|}
\hline \multirow[b]{2}{*}{ Herd } & \multicolumn{4}{|c|}{ Treatment $^{1}$} & \multirow[b]{2}{*}{ Total } \\
\hline & A & B & $\mathrm{C}$ & $\mathrm{D}$ & \\
\hline A & $32.1(9 / 28)$ & $33.3(30 / 90)$ & $29.2(26 / 89)$ & $21.2(18 / 85)$ & $28.4^{\mathrm{a}}(83 / 292)$ \\
\hline $\mathrm{B}$ & $16.7(3 / 18)$ & $26.2(11 / 42)$ & $13.2(5 / 38)$ & $11.9(5 / 42)$ & $17.1^{\mathrm{b}}(24 / 140)$ \\
\hline
\end{tabular}

1998). Nevertheless, even with $70 \%$ power, it is possible that treatment $\mathrm{D}$ resulted in a lower conception rate, but the statistical power of this study was not adequate to detect this difference.

Conception rates differed $(P<0.05)$ between herds (28.4 vs. $17.1 \%)$, and no interaction of herd $\times$ treatment was detected (Table 1). Further, no difference was detected between herds for DIM, milk production, AI service number, or parity.

Using milk progesterone analyses, Reimers et al. (1985) reported the proportion of cows not in or near estrus when inseminated varied from 0 to $60 \%$ among dairy herds. Phatak and Touchberry (1988) reported that the accuracy of tail chalk as an estrus-detection aid varied from 38 to $50 \%$, based on milk progesterone concentration or subsequent pregnancy after AI. Clearly, the misdiagnosis of estrus contributes to poor reproductive performance. Nevertheless, no differences were found between herds in the percentages of cows detected in estrus and inseminated. Therefore, it is unlikely that the difference observed in average conception rate between the herds is due to inaccurate detection of estrus.

Although Pursley et al. (1998) reported similar conception rates for lactating dairy cows inseminated at $0,8,16$, and $24 \mathrm{~h}$ after the second $\mathrm{GnRH}$ injection of the Ovsynch protocol, and those inseminated $32 \mathrm{~h}$ after GnRH had reduced conception rates, conception rates of cows inseminated at 0 to $32 \mathrm{~h}$ after $\mathrm{GnRH}$ produced a quadratic response curve, which peaked at $16 \mathrm{~h}$. In practice, timed AI $16 \mathrm{~h}$ after the second GnRH is inconvenient because it necessitates handling cattle 4 times, with timed AI occurring opposite (a.m. or p.m.) to the previous 3 handlings. Treatment $\mathrm{C}(\mathrm{GnRH}$ and timed AI $64 \mathrm{~h}$ after $\mathrm{PGF}_{2 \alpha}$ ) is a variation of Co-Synch (Geary and Whittier, 1998) and was developed in an effort to reduce animal handling and optimize conception rates. The response time from $\mathrm{PGF}_{2 \alpha}$ to estrus has been reported to be, on average, between 64 and $73 \mathrm{~h}$ (Walker et al., 1996; Dalton et al., 2001). Although a reduction in animal handling occurred, no conception rate advan- tage was detected when administering $\mathrm{GnRH}$ and timed AI together $64 \mathrm{~h}$ after $\mathrm{PGF}_{2 \alpha}$.

In another study investigating variations of Ovsynch (without presynchronization), GnRH and timed AI 72 $\mathrm{h}$ after $\mathrm{PGF}_{2 \alpha}$ appeared to be without benefit compared with $\mathrm{GnRH}$ and timed $\mathrm{AI} 48 \mathrm{~h}$ after $\mathrm{PGF}_{2 \alpha}$ or $\mathrm{GnRH}$ $48 \mathrm{~h}$ after $\mathrm{PGF}_{2 \alpha}$ and timed $\mathrm{AI} 24 \mathrm{~h}$ later (conception rates $=19.1,24.3$, and 27.1\%, respectively; M. A. Portaluppi and J. S. Stevenson, 2005, Kansas State Univ., Manhattan, unpublished data).

In contrast, Portaluppi and Stevenson (2005) reported in another study investigating variations of $\mathrm{Ov}$ synch, that administering $\mathrm{GnRH}$ and first-service timed $\mathrm{AI} 72 \mathrm{~h}$ after $\mathrm{PGF}_{2 \alpha}$ produced greater conception rates (in cows whose estrous cycles were presynchronized) than the other 2 treatments $(\mathrm{GnRH}$ and timed AI $48 \mathrm{~h}$ after $\mathrm{PGF}_{2 \alpha}$, and $\mathrm{GnRH} 48 \mathrm{~h}$ after $\mathrm{PGF}_{2 \alpha}$ and timed AI $24 \mathrm{~h}$ later) combined. Taken together, the optimal time for AI in the Ovsynch protocol may be different depending upon whether presynchronization is used.

In an effort to exploit the average response time from $\mathrm{PGF}_{2 \alpha}$ to estrus, and achieve timed AI without the costly administration of a second GnRH injection, treatment $\mathrm{D}$ was developed. Timed AI (without administration of GnRH) $64 \mathrm{~h}$ after $\mathrm{PGF}_{2 \alpha}$ does not seem to be advantageous. Although the present study had a power of $70 \%$ ( $\alpha=0.05, \beta=30 \%$ ), the probability of a type II error must be considered, as the likelihood of detecting treatment effects may be limited by the number of cows enrolled in the study. In a study utilizing modified targeted breeding $\left(\mathrm{PGF}_{2 \alpha} 14 \mathrm{~d}\right.$ before $\mathrm{GnRH}$, followed $7 \mathrm{~d}$ later by $\mathrm{PGF}_{2 \alpha}$, detection of estrus and $\mathrm{AI}$, with cows not observed in estrus receiving timed AI at $72 \mathrm{~h}$ ), Jordan et al. (2002) suggested that fertility was reduced in cattle not observed in estrus and receiving timed $\mathrm{AI}$ (without administration of $\mathrm{GnRH}) 72 \mathrm{~h}$ after $\mathrm{PGF}_{2 \alpha}$.

Although addition of a controlled internal drug-releasing intravaginal insert containing progesterone into the Ovsynch protocol may solve the problem of precocious spontaneous estrus and ovulation, it adds 
significantly to the cost $(\$ 9.00)$ of the protocol. In contrast, detection of estrus, especially in the form of daily application and reading of tail chalk, is a routine, daily procedure on many farms for all breeding-eligible cattle. Therefore, inclusion of detection of estrus in the Ovsynch protocol may add little, if any, cost to the protocol. Furthermore, a cost savings may actually accrue by using limited detection of estrus, immediate AI, and removal of animals from a protocol because scheduled GnRH and (or) $\mathrm{PGF}_{2 \alpha}$ injections could be eliminated depending upon when a cow came into estrus and received AI (DeJarnette et al., 2001).

In conclusion, although the percentage of cows detected in estrus $\leq 48 \mathrm{~h}$ after $\mathrm{PGF}_{2 \alpha}$ in the present study $(11 \% ; 46 / 432)$ was less than previously reported (20\%; 68/345; DeJarnette et al., 2001), dairy producers should consider carefully the use of Ovsynch without detection of estrus in dairy cows in which estrous cycles are not presynchronized. Cows enrolled in Ovsynch and exhibiting spontaneous estrus before timed AI may not become pregnant because the timed AI occurs after estrus and ovulation. In this scenario, if fertilization occurs, fertilization of an aging ovum would be likely, and reduced embryo quality and reduced conception rates would be expected (Dalton et al., 2001). Lastly, treatment $\mathrm{C}\left(\mathrm{GnRH}\right.$ and timed $\mathrm{AI} 64 \mathrm{~h}$ after $\left.\mathrm{PGF}_{2 \alpha}\right)$ and treatment $\mathrm{D}$ (timed $\mathrm{AI} 64 \mathrm{~h}$ after $\mathrm{PGF}_{2 \alpha}$ without administration of $\mathrm{GnRH}$ ) were unsuccessful in increasing the conception rate.

\section{ACKNOWLEDGMENTS}

This research was supported by a grant to J. C. Dalton and A. Ahmadzadeh from Select Sires Inc. (Plain City, $\mathrm{OH})$. The authors thank Chad Hardy, Tule-View Holsteins (Brigham City, UT), and Mark Tatarka, Frontier Dairy (Buhl, ID) for participation in this research. Pfizer (New York, NY) and Merial (Athens, GA) generously supplied pharmaceuticals.

\section{REFERENCES}

Dalton, J. C., S. Nadir, J. H. Bame, M. Noftsinger, R. L. Nebel, and R. G. Saacke. 2001. Effect of time of insemination, number of accessory sperm, fertilization rate and embryo quality in nonlactating dairy cattle. J. Dairy Sci. 84:2413-2418.

DeJarnette, J. M., R. R. Salverson, and C. E. Marshall. 2001. Incidence of premature estrus in lactating dairy cows and conception rates to standing estrus or fixed-time inseminations after synchronization using GnRH and $\mathrm{PGF}_{2 \alpha}$. Anim. Reprod. Sci. 67:27-35.

El-Zarkouny, S. Z., J. A. Cartmill, B. A. Hensley, and J. S. Stevenson. 2004. Pregnancy in dairy cows after synchronized ovulation regimens with or without presynchronization and progesterone. J. Dairy Sci. 87:1024-1037.

Fricke, P. M., J. N. Guenther, and M. C. Wiltbank. 1998. Efficacy of decreasing the dose of $\mathrm{GnRH}$ used in a protocol for synchronization of ovulation and timed AI in lactating dairy cows. Theriogenology 50:1275-1284.

Geary, T. W., and J. C. Whittier. 1998. Effects of a timed insemination following synchronization of ovulation using the Ovsynch or CoSynch protocol in beef cows. Prof. Anim. Sci. 14:217-220.

Hsieh, F. Y., D. A. Block, and M. D. Larsen. 1998. A simple method of sample size calculation for linear and logistic regression. Stat. Med. 17:1617-1634.

Jordan, E. R., M. J. Schouten, J. W. Quast, A. P. Belschner, and M. A. Tomaszewski. 2002. Comparison of two timed artificial insemination (TAI) protocols for management of first insemination postpartum. J. Dairy Sci. 85:1002-1008.

Moreira, F., C. Orlandi, C. A. Risco, R. Mattos, F. Lopes, and W. W. Thatcher. 2001. Effects of presynchronization and bovine somatotropin on pregnancy rates to a timed artificial insemination protocol in lactating dairy cows. J. Dairy Sci. 84:1646-1659.

National Research Council. 2001. Nutrient Requirements of Dairy Cattle. 7th rev. ed. Natl. Acad. Sci., Washington, DC.

Navanukraw, C., D. A. Redmer, L. P. Reynolds, J. D. Kirsch, A. T. Grazul-Bilska, and P. M. Fricke. 2004. A modified presynchronization protocol improves fertility to timed artificial insemination in lactating dairy cows. J. Dairy Sci. 87:1551-1557.

Phatak, A., and R. W. Touchberry. 1988. Comparison of heat detection aids. J. Dairy Sci. 71(Suppl. 1):136. (Abstr.)

Portaluppi, M. A., and J. S. Stevenson. 2005. Pregnancy rates in lactating dairy cows after presynchronization of estrous cycles and variations of the Ovsynch protocol. J. Dairy Sci. 88:914-921.

Pursley, J. R., M. O. Mee, and M. C. Wiltbank. 1995. Synchronization of ovulation in dairy cows using $\mathrm{PGF}_{2 \alpha}$ and $\mathrm{GnRH}$. Theriogenology 44:915-923.

Pursley, J. R., R. W. Silcox, and M. C. Wiltbank. 1998. Effect of time of artificial insemination on pregnancy rates, calving rates, pregnancy loss, and gender ratio after synchronization of ovulation in lactating dairy cows. J. Dairy Sci. 81:2139-2144.

Pursley, J. R., M. C. Wiltbank, J. S. Stevenson, J. S. Ottobre, H. A. Garverick, and L. L. Anderson. 1997. Pregnancy rates per artificial insemination for cows and heifers inseminated at a synchronized ovulation or synchronized estrus. J. Dairy Sci. 80:295-300.

Reimers, T. J., R. D. Smith, and S. K. Newman. 1985. Management factors affecting reproductive performance of dairy cows in the northeast United States. J. Dairy Sci. 68:963-977.

SAS Institute. 2000. SAS Online Doc, Version 8. SAS Inst., Inc., Cary, NC.

Vasconcelos, J. L. M., R. W. Silcox, G. J. M. Rosa, J. R. Pursley, and M. C. Wiltbank. 1999. Synchronization rate, size of the ovulatory follicle, and pregnancy rate after synchronization of ovulation beginning on different days of the estrous cycle in lactating dairy cows. Theriogenology 52:1067-1078.

Walker, W. L., R. L. Nebel, and M. L. McGilliard. 1996. Time of ovulation relative to mounting activity in dairy cattle. J. Dairy Sci. 79:1555-1561. 